\title{
The profile of spinal injuries in the elderly population
}

\author{
Perfil do trauma raquimedular em idosos
}

Perfil del trauma raquimedular en ancianos

Glaciéle de Oliveira Teixeira', Thais Fonseca de Oliveira², Verônica Baptista Frison³, Thais de Lima Resende ${ }^{4}$

\begin{abstract}
I This retrospective cross-sectional study sought to: describe the profile of the elderly population who suffered spinal injury (SI) between 2005 and 2010 in Porto Alegre (RS), Brazil; compare the trauma mechanism and type of SI prevalence in both sexes; and compare the trauma mechanism in the sample's age groups. To this end, medical records were reviewed for the following data: age, sex, main mechanisms of injury and spinal levels affected. Out of 1.320 records analyzed, 370 belonged to elderly subjects, 58.6\% women (73.07 \pm 8.52 years) and $41.4 \%$ men (69.4 \pm 7.5 years). The most prevalent SI mechanisms were falls from own height (37.7\%), height (24.3\%) and unspecified (20.1\%). The most affected vertebral levels were L1 (30.0\%), T12 (16.2\%) and L2 (11.9\%). Only 26 (7\%) individuals who had SI suffered a spinal cord lesion, with a higher prevalence of incomplete lesion (82.6\%). No significant association was detected between the occurrence of SI and its type or sex. In the time and region investigated, the SI profile in the elderly can be described as: women over 70, who suffered a fall from their own height, injuring mainly the lumbar region. Elderly men and women were equally affected by SI without spinal cord lesion. Falls from height predominated in those aged 60-69, whereas falls from own height were commonest among those aged 70 and over.
\end{abstract}

Keywords I Spinal injuries; Spinal Cord Compression; Spinal Cord Injuries; Aged.

RESUMOIEste estudo transversal retrospectivo teve como objetivos: traçar o perfil da população idosa que sofreu trauma raquimedular (TRM) entre 2005 e 2010 em Porto
Alegre (RS), Brasil; comparar a prevalência nos sexos dos diferentes mecanismos de trauma e do tipo de lesão medular; e comparar o mecanismo de trauma de acordo com a faixa etária da amostra. A coleta em prontuários de dois Serviços de Arquivo Médico (SAME) envolveu os seguintes dados: idade, sexo, principais mecanismos de lesão e níveis medulares mais acometidos. Foram analisados 1.320 prontuários, dos quais 370 eram de idosos; destes, 58,6\% eram de muIheres (73,07 $\pm 8,52$ anos) e 41,4\% de homens (69,4 $\pm 7,5$ anos). Prevaleceram quedas da própria altura (37,7\%), quedas de altura (24,3\%) e quedas sem especificação (20,1\%). Os níveis vertebrais mais acometidos foram L1 (30,0\%), T12 (16,2\%) e L2 (11,9\%). Apenas 26 (7\%) dos indivíduos que sofreram TRM apresentaram lesão medular, com maior prevalência da incompleta (82,6\%). Não foi detectada associação significativa entre a ocorrência de TRM ou o seu tipo e sexo. O perfil do TRM em idosos da região pode ser descrito como: mulheres acima de 70 anos que sofreram queda da própria altura, lesionando principalmente a região lombar. Idosos e idosas foram igualmente acometidos por TRM sem lesão medular, com predomínio de quedas de altura na faixa dos 60 anos e quedas da própria altura acima dos 70 anos.

Descritores I Traumatismos da Coluna Vertebral; Compressão da Medula Espinal; Traumatismos da Medula Espinal; Idoso.

RESUMEN I Este estudio transversal retrospectivo tuvo como objetivos: definir el perfil de la población de edad avanzada que sufrió trauma raquimedular (TRM) entre 2005 y 2010 en Porto Alegre (RS), Brasil; comparar la prevalencia en los sexos de los diferentes mecanismos de

Study conducted at the School of Nursing, Nutrition and Physical Therapy of the Pontifícia Universidade Católica do Rio Grande do Sul (FAENFI/PUCRS) - Porto Alegre (RS), Brazil.

'Specialist in Integrated Geriatric Care by the Institute of Geriatrics and Gerontology of the PUCRS - Porto Alegre (RS), Brazil.

${ }^{2}$ Physical Therapy graduate from the FAENFI/PUCRS - Porto Alegre (RS), Brazil.

${ }^{3}$ Lecturer at the FAENFI/PUCRS - Porto Alegre (RS), Brazil.

${ }^{4}$ Professor at the FAENFI/PUCRS - Porto Alegre (RS), Brazil. 
trauma y el tipo de lesión medular; y comparar el mecanismo de trauma de acuerdo con la franja etaria de la muestra. La recogida de los registros de dos Servicios de Archivo Médico (SAME) involucró los siguientes datos: edad, sexo, principales mecanismos de lesión y niveles medulares más afectados. Se analizaron 1.320 registros, de los cuales 370 eran ancianos; de estos, 58,6 \% eran

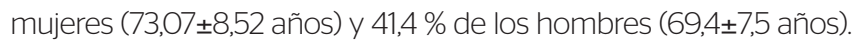
Prevalecieron caídas desde la propia altura (37,7\%), caídas desde altura (24,3\%) y caídas sin especificación (20,1\%). Los niveles vertebrales más afectados fueron L1 (30,0 \%), T12 (16,2 \%) y L2 (11,9\%). Solo 26 (7 \%) de los individuos que han sufrido TRM presentaron lesión medular, con mayor prevalencia de la incompleta (82,6 \%). No se encontró asociación significativa entre la ocurrencia de TRM o su tipo y sexo. El perfil del TRM en mayores de la región puede ser descrito como: mujeres mayores de 70 años que sufrieron caídas desde la propia altura, lesionando principalmente la región lumbar. Ancianas y ancianos también se vieron afectados por TRM sin lesión medular, con un predominio de caídas desde altura en la franja de los 60 años y caídas desde la propia altura arriba de los 70 años.

Palabras clave I Traumatismos Vertebrales; Compresión da la Médula Espinal; Anciano.

\section{INTRODUCTION}

The technological advances and improved quality of life allow individuals in old age to continue carrying out activities attributed to younger age groups ${ }^{1,2}$. The increase in longevity, associated with the increase in the elderly population in Brazil and also the more active life style of the elderly, has led to increased cases of trauma in the geriatric population ${ }^{3,4}$. Trauma is the fifth leading cause of death in the elderly $^{3,4}$. After a trauma, the elderly remains hospitalized from 1 to 52 days $^{5}$, while young adults remain hospitalized between 2 and 10 days $^{6}$.

Although the elderly suffer the same injuries as the young individuals, they differ in relation to the range of the injuries, their duration and evolution. They present themselves in a more critical way, require hospitalization more often, represent a large proportion of patients in Intensive Care Units and consume more resources than any other age group ${ }^{2,7}$.

Some factors are seen as facilitators of trauma in the elderly, such as the worsening of proprioception, the presence of tremors which hinder walking, slow defense reflexes and tissue changes featured at of old age $^{2,3,7}$. These changes are associated to those relating to the control of balance, causing pace instability, which, associated with the interaction of various environmental and the individual's factors, may result in fall ${ }^{8}$. The fractures in the elderly are usually caused by small and unintentional traumas, such as falls ${ }^{8-12}$. A spinal cord injury occurs in about 15 to $20 \%$ of spinal fractures, falls being one of its main causes ${ }^{13}$.

Thus, the prevention of falls is a challenge of the aging population. Worldwide, the number of falls increases in magnitude as the number of elderly people increases. In case no preventive measures are taken, the number of injuries from falls is predicted to be $100 \%$ higher in $2030^{10}$.

From this scenario emerges the need for more studies, considering that the traumatic event in the elderly affects the collective and family spheres, denoting high costs, in economic terms and in terms of the suffering of the victim ${ }^{1,10}$. Although it is noted that in the literature the theme trauma in the elderly has been increasingly exploited, this problem remains little discussed in the academic and public health areas. In particular, there is a lack of this kind of scientific record in the state of Rio Grande do Sul and in Brazil.

Therefore, this study aimed to define the epidemiological profile of elderly patients with spinal cord injury (SCI) in Porto Alegre between 2005 and 2010, identifying the following characteristics of the studied group: sex, age and age range, the mechanism of the trauma, vertebral level of the injury, the type and level of the injury. The intention was also to compare the prevalence, in genders, of different mechanisms of trauma and the type of injury, as well as to compare the mechanism of trauma according to the age range of the sample.

\section{METHODOLOGY}

This cross-sectional retrospective study was developed from the data collection from patient records in the Service of Medical Records (SAME) of the two referral hospitals for SCI in Porto Alegre. The collection is relative to the period of 2005-2010. 


\section{Procedures}

All medical chart records which had their corresponding certificate of the International Code of Diseases (ICD) were checked over from the admission to the discharge moment. If in this period it was found that it was not a case of SCI, the data from this medical records were excluded.

Data collected included: age, gender, injury/trauma mechanism, spinal levels affected by trauma, spinal cord injury level, type of spinal cord injury.

The mechanisms of injury found were: assault, traffic accidents, falls, falls from height, falls from benches, horse falls, falls from their own height, weight drop on the body, orthopedic trauma and unspecified mechanism. The mechanism "fall" was registered when there was no kind of specification in the medical chart beyond this description. Fall from height was considered to be that one occurred from a height higher than the elderly's height itself.

Traffic accidents correspond to the mechanism involving the elderly as a driver, passenger or pedestrian.

The types of spinal cord injury were: complete, incomplete, without spinal cord implication or undefined $^{6}$, when it was not specified in the chart if it was complete or incomplete.

\section{Statistical analysis}

The data was statistically analyzed by using the SPSS 17.0 software. The significance level was ( $\alpha$ ) of $5 \%$.

Those cases in which a given datum was not found in the medical records were not considered valid and thus excluded, which resulted in different sample sizes for some of the analyses carried out.

Gender and age were the independent variables. The dependent variables, all of them polytomous categorical, were: mechanism of the trauma, vertebral level of the injury, type and level of the injury.

The results regarding age were presented as average and standard deviation and range, and their distribution was investigated by the Kolmogorov-Smirnov test. Categorical variables were presented through the absolute and relative distribution.

The $\chi^{2}$ test was used to compare proportions between categories of the same variable (univariate analysis), as well as for the bivariate analysis between qualitative variables, taking into account the theoretical distribution of homogeneity among the compared categories. In the contingency tables in which at least $25 \%$ of the values of the cells had expected frequencies lower than five, the Fisher's exact test was used. In situations where at least one qualitative variable had polytomous characteristics, the Fisher's exact test with the Monte Carlo simulation was used. The Mann-Whitney test was used for comparing the continuous variables between independent groups.

This study was approved by the Ethics Committee in Research of the Grupo Hospitalar Conceição (No.10-010), of the Grupo Hospitalar Conceição (No. 10-010) and of the Secretaria Municipal da Saúde de Porto Alegre (process No. 001.004651.10.3; registry 458).

\section{RESULTS}

A total of 1,320 records of individuals who suffered SI was found, of which 370 were elderly ( $>60$ years of age; $28 \%$ ). Out of the total elderly subjects' records (Table 1 ), $58.6 \%$ were women $(73.1 \pm 8.5$ years of age $)$ and $41.4 \%$ were men $(69.4 \pm 7.5$ years of age).

\section{Mechanism of trauma and the most affected levels of the spine}

In relation to the trauma mechanism (Table 1), falls from one's own height prevailed (37.7\%), followed by falls from heights (24.3\%) and falls (20.1\%). For this analysis, the 329 valid cases were considered, excluding the records without any specification of the injury's mechanism.

Considering all the trauma mechanisms described (Table 1), the most affected spinal levels were L1 (30.0\%), T12 (16.2\%) and L2 (11.9\%). For 20.8\% of the elderly, the injured vertebral level was not specified.

Table 1. Absolute and relative distribution of the mechanism and level of trauma for the total sample according to the gender

$\begin{array}{lccc}\text { Variables } & \begin{array}{c}\text { Total } \\ (\mathrm{n}=370) \\ \mathrm{n}(\%)\end{array} & \begin{array}{c}\text { Women } \\ (\mathrm{n}=217) \\ \mathrm{n}(\%)\end{array} & \begin{array}{c}\text { Men } \\ (\mathrm{n}=153) \\ \mathrm{n}(\%)\end{array} \\ \text { Mechanism of trauma } & & & \\ \text { Falls from one's own height } & 124(37.7) & 100(80.6) & 24(19.4) \\ \text { Falls from heights } & 80(24.3) & 24(30) & 56(70) \\ \text { Falls } & 66(20.1) & 47(71.2) & 19(28.8) \\ \text { Traffic accidents } & 45(3.7) & 20(44.4) & 25(55.6) \\ \text { Level of the trauma } & & & \\ \text { Lumbar vertebrae L1 } & 111(30.0) & 70(63.1) & 41(36.9) \\ \text { Lumbar vertebrae L2 } & 44(11.9) & 24(54.5) & 20(45.5) \\ \text { Thoracic vertebrae T11 } & 17(4.6) & 14(82.3) & 3(17.7) \\ \text { Thoracic vertebrae T12 } & 60(16.2) & 38(63.3) & 22(36.7) \\ \text { Not specified } & 77(20.8) & 47(61) & 30(39)\end{array}$


No statistically significant association between gender and the occurrence of SI, or its type, was detected.

\section{Vertebral level involved in major trauma mechanisms}

In falls from one's own height (Table 2), the most frequent levels of trauma were L1 (32.3\%), T12 (21.8\%) and L2 (16.9\%). Of the total number of falls from height, $80.6 \%$ happened to women.

For falls from heights (Table 2), the levels of trauma were more prevalent in L1 (36.3\%), T12 (17.5\%) and L2. In this mechanism, there was a predominance of men (70\%).

In falls (Table 2), the levels L1 (39\%), T12 (10.4\%) and T11 (9.1\%) predominated, and they were most prevalent among women (71.2\%).

Traffic accidents accounted for $13.7 \%$ of the trauma mechanisms (Table 2), whose most frequent trauma levels were T12 (20.0\%), L2 (15.6\%), L1 and C6, each of them observed in $13.3 \%$ of the elderly.

\section{Mechanism of injury in each age group}

A significant association was detected between the mechanism of injury and age range (Table 3): the group of 60 to 69 years of age was associated with falls from heights $(29.2 \%)$, the one from 70 to 79 to falls from one's own height (41.4\%) and the over 80 years of age to falls from one's own height (45.1\%) and falls (28.2\%).

\section{Type and level of the spinal injury}

Of the total of SI elderly victims (Table 4), those without spinal cord injury predominated (93\%). In 7\% of the total sample who suffered spinal cord injury ( $n=23$ ), two subjects had complete spinal cord injury, 19 had an incomplete lesion and for the remaining two subjects there was no specification whether it was complete or incomplete." spinal cord injury. The most frequently affected levels were L1 (23.1\%), followed by $\mathrm{C} 5$ and T12, each of them observed in $19.2 \%$ of the cases. The mechanisms of trauma which resulted in spinal cord lesion were traffic accidents (35.3\%), falls from a height (35.3\%), falls (17.7\%) and falls from one's own height (11.8\%). The two most prevalent mechanisms that resulted in spinal cord injury (70.6\%), traffic accidents and falls from heights, were most prevalent among men (66.7\%).

It was not possible to perform the inferential analysis on the level of spinal cord injury, due to the reduced sample size.
Table 2. Distribution of the vertebral level of the trauma in relation to the main mechanisms of trauma

\begin{tabular}{lcccc} 
& \multicolumn{5}{c}{ Vertebral level of the trauma } \\
\cline { 2 - 5 } Mechanism of trauma & T11 & T12 & L1 & L2 \\
Falls from one's own height $(n=124)$ & $*$ & $27(21.8)$ & $40(32.3)$ & $21(16.9)$ \\
Falls from height $(n=80)$ & $*$ & $14(17.5)$ & $29(36.6)$ & $10(12.5)$ \\
Falls ( $n=66)$ & $6(9.1)$ & $7(10.4)$ & $26(39)$ & $*$ \\
Traffic accidents $(n=45)$ & $*$ & $9(20.0)$ & $6(13.3)$ & $7(15.6)$
\end{tabular}

${ }^{*}$ The mechanisms of trauma related to these vertebral levels were not found in the medical records; T11 and T12: thoracic vertebraes 11 and 12; L1 and L2: lumbar vertebraes 1 and 2

Table 3. Absolute and relative distribution of the trauma mechanism according to the age group $(n=370)$

\begin{tabular}{lccc} 
& \multicolumn{3}{c}{$\begin{array}{c}\text { Age range * } \\
\mathbf{n}(\%)\end{array}$} \\
\cline { 2 - 4 } Mechanisms of trauma & $\begin{array}{c}60-69 \\
(\mathbf{n}=171)\end{array}$ & $\begin{array}{c}70-79 \\
(\mathbf{n}=128)\end{array}$ & $\begin{array}{c}\geq 80 \\
(\mathbf{n}=71)\end{array}$ \\
\hline $\begin{array}{l}\text { Physical aggression } \\
\text { Traffic accidents }\end{array}$ & $26(15.2)$ & $14(10.9)$ & $5(7.0)$ \\
Not specified & $24(14.1)$ & $14(11.0)$ & $8(11.2)$ \\
Falls & $24(14.0)$ & $22(17.2)$ & $20(28.2)$ \\
Falls from heights & $50(29.2)$ & $24(18.8)$ & $6(8.5)$ \\
Falls from benches & $2(1.2)$ & & \\
Falls from horses & & $1(0.8)$ & \\
Fall from one's own height & $39(22.8)$ & $53(41.4)$ & $32(45.1)$ \\
Fall of weight over the body & $3(1.8)$ & & \\
Orthopedic traumas & $2(1.2)$ & & \\
Probability & & $<0.001^{\&}$
\end{tabular}

*Percentages obtained based on the total overall of each age range; ${ }^{\circledR}$ Fisher's exact test by Monte Carlo simulation

Table 4. Absolute and relative distribution of type and level of the spinal cord injury in elderly according to gender

\begin{tabular}{|c|c|c|c|}
\hline \multirow{2}{*}{ Variables } & \multicolumn{2}{|c|}{$\begin{array}{c}\text { Gender } \\
\text { n (\%) }\end{array}$} & \multirow{2}{*}{ p-value } \\
\hline & $\begin{array}{l}\text { Female } \\
(n=217)\end{array}$ & $\begin{array}{c}\text { Male } \\
(n=153)\end{array}$ & \\
\hline \multicolumn{4}{|l|}{ Spinal Cord injury } \\
\hline Complete Spinal Cord injury & $1(0.5)$ & $1(0.7)$ & \multirow{18}{*}{$0.284^{\&}$} \\
\hline Incomplete Spinal Cord injury & $7(3.2)$ & $12(7.8)$ & \\
\hline Not defined ${ }^{\#}$ & $2(1.0)$ & 0 & \\
\hline No injury to the Spinal Cord & $160(73.7)$ & $106(69.3)$ & \\
\hline Level of the spinal cord injury & $(n=12)^{*}$ & $(n=14)^{\star}$ & \\
\hline Cervical vertebrae C2 & $1(8.3)$ & $1(7.1)$ & \\
\hline Cervical vertebrae C4 & & $1(7.1)$ & \\
\hline Cervical vertebrae C5 & $1(8.3)$ & $4(28.6)$ & \\
\hline Cervical vertebrae C6 & & $1(7.1)$ & \\
\hline Lumbar vertebrae L1 & $1(8.3)$ & $5(35.7)$ & \\
\hline Lumbar vertebrae L2 & $1(8.3)$ & $1(7.1)$ & \\
\hline Thoracic vertebrae T4 & & $1(7.1)$ & \\
\hline Thoracic vertebrae T5 & & $1(7.1)$ & \\
\hline Thoracic vertebrae T6 & & $1(7.1)$ & \\
\hline Thoracic vertebrae T10 & $1(8.3)$ & & \\
\hline Thoracic vertebrae T11 & $3(25.0)$ & & \\
\hline Thoracic vertebrae T12 & $4(33.3)$ & $1(7.1)$ & \\
\hline Not specified & $1(8.3)$ & & \\
\hline
\end{tabular}

*the total sample is higher than the sample size for each sex (female=12; male=14), because there were people who injured more than one spinal level; \&Fisher's exact test by Monte Carlo simulation. "Not defined: the definition whether the injury was complete or incomplete was not found in the medical record 
Nevertheless, in the descriptive analysis (Table 4), it was possible to observe that in the women the most frequently affected levels were $\mathrm{T} 12$ (33.3\%, 4/12) and T11 (25.0\%, $3 / 12)$, while in the men prevailed L1 $(35.7 \%, 5 / 14)$ and C5 $(28.6 \%, 4 / 14)$.

\section{DISCUSSION}

The present study shows that the SI affects elderly women more, with an average age in accordance with that found in other studies $1,3,4,7,11,12,14$. As to the etiology, the main mechanisms of SI in the elderly were falls from their own height, followed by falls from heights and falls.

In a city where the elderly population corresponds to $15 \%$ of the total population ${ }^{15}$, the high prevalence of SI in the elderly (28\%), particularly among women, might be explained by the prevalence of predisposing conditions resulting from senescence ${ }^{10,12,16}$, comorbidities $^{2}$ and an increased risk of trauma ${ }^{10}$.

The prevalence of falls from height found (37.7\%) is much lower than the $80 \%$ found in 2 studies conducted in Campinas (SP, Brazil) ${ }^{1,12}$. This large difference between the percentages of falls from one's own height in the three studies (42.3\%) may result from the different locations where the data were collected, the conditions of the collection period and/or its total time. Whilst for the present study the medical records from the two SI regional referral hospitals were reviewed for a five-year period, the study of Lima and Campos ${ }^{1}$ was developed in an Emergency Department Unit during three months of lower temperatures (June to August) and the study of Jahana and Diogo ${ }^{12}$ aimed at studying the causes and consequences of falls in elderly.

As for the falls from heights, the findings of this study $(24.3 \%)$ were similar to the $19 \%$ of Jahana and Diogo $^{12}$, but much higher than the $6 \%$ reported by Lima and Campos ${ }^{1}$. This difference may be related to the used definition of falls from height, which in this study was considered as all falls that occurred at a level higher than the elderly subjects' own height, while Lima and Campos $^{1}$ considered only falls from ladders, roofs and stairs. The high rate of falls from heights may be related to the maintenance of functional independence, which enables older people to carry out activities which make them more susceptible to accidents ${ }^{1}$. In this case, it would befit developing health education strategies for the city's elderly population, in order to prevent this kind of fall. Seniors and their families need to be informed about the risks involved in relatively simple activities, but which become inadvisable with the advancing of age, such as changing light bulbs or reaching out for objects far above shoulder height, which involve the extension of the head, that may lead to reduced blood flow in the vertebral and basilar arteries causing dizziness, loss of balance and falls ${ }^{17}$.

The falls, without any other type of description, represented $20.1 \%$ of the SIs in this study. It is possible that this percentage includes falls from heights and from one's own height. Biazin et al. ${ }^{4}$ profiled the elderly who suffered trauma in Londrina (PR, Brazil) and presented falls as the primary mechanism, with a prevalence of $62 \%$. This higher prevalence found may be explained by the fact that the authors did not analyze the falls into subgroups ${ }^{4}$. Adding up the present study's three types of falls an $82.1 \%$ value is reached, which exceeds their percentage.

The prevalence of another important SI etiology in the elderly, the traffic accidents (13.7\%), was similar to the $13 \%$ found by Lima and Campos ${ }^{1}$, who mainly reported vehicle run-overs and falls in public transportation due to unexpected bumps and braking, an information commonly found in the medical records examined for this study. Barbosa et al. ${ }^{11}$ also recognized traffic accidents as one of the main trauma mechanisms in the elderly (16.8\%).

In Porto Alegre, the external causes are responsible for $10.1 \%$ of deaths, affecting more men than women by a ratio of almost $4 / 1$, and nearly one-third of these deaths affects elderly. Falls and traffic accidents predominate as causes of hospitalization and deaths among elderly in this capital, and, in terms of mortality, falls are second only to murder in the age groups 15 to 24 years $(75.5 \%)$ and 25 to 45 years $(69 \%)^{18}$. Thus, in order to reduce the occurrence of falls and traffic accidents among the elderly, it is clear the need for preventive measures. Among the possible actions, quoted even by the Secretaria Municipal de Saúde ${ }^{18}$ (City's Department of Health), are the measures aimed at reducing the risk of falls, the prevention of falls in the home environment, professional training for the care of the elderly with increased risk of fragility and adjusting the adequacy of the urban architecture and public buildings. Notwithstanding, it is also point out here the need for educating drivers in general as to the characteristics which make the elderly more likely to suffer traffic accidents, either as pedestrians or passengers.

In this study, the spinal levels most affected by trauma in the elderly (L1, L2, T12) are in accordance with the 
findings of Wang et al. ${ }^{19}$ and Pirouzmand ${ }^{20}$, who found the thoracolumbar (40.5\%) and lumbar (50\%) levels as the most injuried ones, respectively. It is likely that the high prevalence of falls from one's own height and falls from heights is responsible for the increased involvement of the lumbar level in this study, since these trauma mechanisms often lead to injuries in this region ${ }^{19,20}$.

Falls accounted for $82 \%$ of the SI etiologies in this study, confirming the importance of valuing the fall event, since it brings many consequences, some irreparable, including death. Accidental injuries are the sixth leading cause of death among individuals aged 75 years of age or more, and falls account for $70 \%$ of this mortality rate ${ }^{21}$. The latter is recognized as a sentinel event in the lives of seniors, an important marker of the beginning of the functional decline, with effects which arise in the physical, functional, psychosocial, and economic spheres $^{22}$ causing significant negative impact on the quality of life of this population ${ }^{23}$.

The increasing number of falls with increasing age found is consistent with the worldwide literature ${ }^{10,20,22,24}$. In the elderly population, injuries caused by falls are related to the slowing of the reflexes and the decrease of the defense mechanisms at the time of the accident ${ }^{3,12}$. Tremors which appear with the aging process and which reduce the balance also increase the frequency of the falls ${ }^{3,10,12}$.

One way to minimize most of the losses resulting from aging is the practice of physical activity, which may decrease, among others, the occurrence of fall ${ }^{20}$. It improves the overall health of the elderly and its encouragement is an important measure for the prevention of falls ${ }^{20,25-27}$. This therapeutical modality improves physical mobility and postural stability, which are causes directly related to the reduction of fall ${ }^{25}$, and it may also improve neuromuscular function, gait and balance, which are determining factors for falls ${ }^{26}$.

According to the Global Report of the World Health Organization (WHO) on the prevention of falls in old age $^{10}$, besides maintaining an acceptable level of physical activity, not smoking, drinking alcohol moderately, keeping the weight at normal levels in midlife and in old age are also important protective factors against falls. Aside from these cares, it should also be carried out a review of medications, changes in the home to promote their safety and the promotion of safety outside the home $\mathrm{e}^{10,20,24}$.

Multidisciplinary interventions may assist in the prevetion of falls at a population level ${ }^{20}$. For that, it is necessary that states and municipalities train the health professionals and, in fact, make the elderly health care a government policy. Thus, for the promotion of healthy aging it is imperative and urgent to have a program which raises the awareness of the society and of the elderly themselves on the measures that reduce the risk for falls, allowing the elderly to stay in their home environment and with their functional capacity preserved ${ }^{21}$.

It is noteworthy that the urban and public buildings architectural appropriateness is an important step for the reduction of the risks with which the elderly deal with in their daily activities. In a society engaged in promoting active aging, the operative word is accessibility ${ }^{10}$.

Another important aspect in both the acute care of SI in the elderly and its rehabilitation is the prejudice against old people found among scientists and health professionals, as reported in the literature ${ }^{28}$. The potential effects of such bias on the results of the care of the elderly SI victims cannot be excluded, as pointed out by Furlan and Fehlings ${ }^{2}$ in their study in which it was observed that, although the elderly have shown greater sensorial recovery in the first year after a spinal injury, it did not translate itself into better functional outcomes, since older age was associated with greater disability as assessed by the Functional Independence Measure. Therefore, it is necessary to have proper training for the health care of the elderly during professional training, as well as regular training updates thereafter, until this culture permeated by prejudice against the elderly is changed.

The development of this study occurred in the face of some limitations and difficulties, such as: the need for manual searches of the medical records, many of which with no data and/or incomplete data; the inadequate storage of the records; and the lack of standardization of the registry of the individuals with SI. The standardization of the registry process in hospitals can make the prognosis more accurate, expedite the treatment and lead to better rehabilitation through the precise knowledge of the type of injury ${ }^{29}$.

\section{CONCLUSION}

Based on the population and the period studied, it can be concluded that the profile of the elderly affected by SI in metropolitan area of Porto Alegre can be described as: women above 70 years, with fall from own height as the most frequent etiology and the lumbar level as the most affected. Elderly men and women were equally affected by SI without spinal cord injury, whose mechanism 
varied according to the age group, with prevalence of falls from height in the 60 years group and falls from own height in those above 70 years.

These results indicate that, given the most prevalent trauma mechanisms in the elderly and the rapid growth of the elderly population, it is necessary do adopt a proactive and systematic prevention approach, which integrates policies, preventive and practical measures.

\section{REFERENCES}

1. Lima RS, Campos MLP. Perfil do idoso vítima de trauma atendido em uma unidade de urgência e emergência. Rev Esc Enferm USP. 2011:45(3):659-64.

2. Furlan JC, Fehlings MG. The impact of age on mortality, impairment, and disability among adults with acute traumatic spinal cord injury. J Neurotrauma. 2009;26(10):1707-17.

3. Cintra Jr W, Coutinho MC, Rocha RI, Massarolo LC. Fraturas de ossos da face na população idosa: etiologia e tratamento. Rev Soc Bras Cir Craniomaxilofac. 2008;11(3 Suppl):22-22.

4. Biazin DT, Rodrigues RAP. Perfil dos idosos que sofreram trauma em Londrina. Rev Esc Enferm USP. 2009:43(3):602-8.

5. Paula FL, Fonseca MJM, Oliveira RVC, Rozenfeld S. Perfil de idosos com internação por quedas nos hospitais públicos de Niterói (RJ). Rev Bras Epidemiol. 2010;13(4):587-95.

6. Lenehan B, Street J, Kwon BK, Noonan V, Zhang H, Fisher CG, et al. The epidemiology of traumatic spinal cord injury in British Columbia, Canada. Spine (Phila Pa 1976). 2012;37(4):321-9.

7. Pereira CV, Almeida AMG. Traumatismo Cranioencefálico leve no idoso. J Bras Neurocir. 2009;20(3):356-61.

8. Muniz CF, Arnaut AC, Yoshida M, Trelha CS. Caracterização dos idosos com fratura do fêmur proximal atendidos em hospital-escola público. Rev Espaço Saúde. 2007;8(2):33-8.

9. Parreira JG, Vianna AMF, Cardoso GS, Karakhanian WZ, Calil D, Perlingeiro JAG, et al. Lesões graves em vítimas de queda da própria altura. Rev Assoc Med Bras. 2010;56(6):660-4.

10. Campos LM, Rehder S, Rosado M. Relatório global da Organização Mundial da Saúde sobre prevenção de quedas na velhice. São Paulo: Secretaria de Estado da Saúde; 2010.

11. Barbosa MLJ, Nascimento EFA. Incidência de internações de idosos por motivo de quedas, em um hospital geral de Taubaté. Rev Biociênc. 2001;7(1):35-42.

12. Jahana KO, Diogo MJDE. Quedas em idosos: principais causas e consequências. Rev Saúde Coletiva. 2007:4(17):148-53.

13. Souza LC, Ortega MR, Ribeiro-Junior MAF. Trauma raquimedular e choque neurogênico: manifestações incomuns de instabilidade hemodinâmica - como diagnosticar e tratar corretamente. Rev Emergência Clínica. 2010;5(24):87-9.
14. Campos JFS, Poletti NAA, Rodrigues CDS, Garcia TPR, Angelini JF, Von Dollinger APA, et al. Trauma em idosos atendidos no pronto atendimento da emergência do hospital de base. Arq Ciênc Saúde. 2007;14(4):193-7.

15. Brasil. Ministério do Planejamento, Orçamento e Gestão. Instituto Brasileiro de Geografia e Estatística [Internet]. Censo 2010. [Citado em 05 fev 2014]. Disponível em: <http://www.ibge.gov.br/home/ estatistica/populacao/censo2000>

16. Siqueira FV, Facchini LA, Piccini RX, Tomasi E, Thumé E, Silveira DS, et al. Prevalência de quedas em idosos e fatores associados. Rev Saúde Pública. 2007:41(5):749-56.

17. Jackson RT, De l'Aune WR. Head extension and age-dependent posturographic instability in normal subjects. J Rehabil Res Dev. 1996;33(1):1-5.

18. Prefeitura Municipal de Porto Alegre. Secretaria Municipal de Saúde [Internet]. Plano Municipal de Saúde 2010-2013. Porto Alegre; 2010. [Citado em 03 fev 2013]. Disponível em: <http://lproweb.procempa. com.br/pmpa/prefpoa/sms/usu_doc/pms.pdf>

19. Wang $\mathrm{H}$, LiC, Xiang $\mathrm{Q}$, Xiong $\mathrm{H}, \mathrm{Zhou}$ Y. Epidemiology of spinal fractures among the elderly in Chongqing, China. Injury. 2012;43(12):2109-16.

20. Pirouzmand F. Epidemiological trends of spine and spinal Cord injuries in the largest Canadian adult trauma center from 1986 to 2006. J Neurosurg Spine. 2010;12(2):131-40.

21. Fabrício SCC, Rodrigues RAP, Junior MLC. Causas e consequências de quedas de idosos atendidos em hospital público. Rev Saúde Pública. 2004;38(1):93-9.

22. Stenhagen $M$, Ekström $H$, Nordell E, Elmståhl S. Accidental falls, health-related quality of life and life satisfaction: A prospective study of the general elderly population. Arch Gerontol Geriatr. 2014:58(1):95-100.

23. Ribeiro AP, Souza ER, Atie S, Souza AC, Schilithz AO. A influência das quedas na qualidade de vida de idosos. Ciênc Saúde Coletiva. 2008:13(4):1265-73.

24. Persad CC, Cook S, Giordani B. Assessing falls in the elderly: should we use simple screening tests or a comprehensive fall risk evaluation? Eur J Phys Rehabil Med. 2010;46(2):249-59.

25. Pimentel RM, Scheicher ME. Comparação do risco de queda em idosos sedentários e ativos por meio da escala de equilíbrio de Berg. Fisioter Pesqui. 2009;16(1):6-10.

26. Muir SW, Gopaul K, Montero Odasso MM. The role of cognitive impairment in fall risk among older adults: a systematic review and meta-analysis. Age Ageing. 2012;41(3):299-308.

27. Gillespie LD, Robertson MC, Gillespie WJ, Lamb SE, Gates S, Cumming RG, et al. Interventions for preventing falls in older people living in the community. Cochrane Database Syst Rev. 2012;9:CDO07146.

28. Furlan JC, Fehlings MG. Attitudes toward the elderly with CNS trauma: A cross-sectional study of neuroscientists, clinicians and allied-health professionals. J. Neurotrauma. 2009;26(2):209-25.

29. Araújo Júnior FA, Heinrich CB, Cunha MLV, Veríssimo DCA, Rehder R. Pinto CAS, et al. Traumatismo raquimedular por ferimento de projétil de arma de fogo: avaliação epidemiológica. Coluna/Columna. 2011:10(4):290-2 